\title{
PELATIHAN METODE TPR UNTUK MENINGKATKAN KEMAMPUAN BERBICARA DAN KREATIVITAS SISWA DI TINGKAT SMP, DESA JALANCAGAK, KABUPATEN SUBANG
}

\author{
Cynantia Rachmijati ${ }^{1}$, Anita Anggraeni ${ }^{2}$, Dewi Listia Apriliyanti ${ }^{3}$ \\ 1,2,3 Fakultas Bahasa dan Seni, IKIP SILIWANGI \\ cynantiarachmijati@ikipsiliwangi.ac.id¹
}

\begin{abstract}
ABSTRAK
Pendidikan bahasa Inggris diberikan di Indonesia kepada siswa diawali dari tingkat Sekolah Dasar hingga Perguruan Tinggi. Karena karakteristik anak-anak sebagai pembelajar berbahasa berbeda dan unik dibandingkan dengan pembelajar dewasa sehingga dibutuhkan metode yang berbeda. Level pendidikan di Desa Jalancagak, Subang yang masih belum merata membutuhkan penyegaran metode pembelajaran, terutama terkait dalam pembelajaran bahasa Inggris Pengabdian kepada masyarakat yang berjudul "Penerapan metode TPR untuk meningkatkan kemampuan berbicara dan kreativitas siswa" ini bertujuan untuk memberikan wawasan pengetahuan kepada para guru TK tentang penerapan metode TPR serta memberikan bekal kemampuan untuk mengajar pada anak usia sekolah dasar. Metode TPR (Total Physical Response) merupakan suatu metode pembelajaran bahasa yang disusun pada koordinasi perintah (command), ucapan (speech) dan gerak (action); dan berusaha untuk mengajarkan bahasa melalui aktivitas fisik (motor). Penyampaian materi pengabdian antara lain meliputi pengertian, manfaat, implementasi dan adaptasi dari metode TPR. Diharapkan para guru bisa menerapkan metode ini dalam kegiatan belajar mengajar sehingga bisa meningkatkan kemampuan berbicara dan kreativitas siswa sekaligus memberikan pengetahuan terkait metode mengajar baik secara konvensional maupun menggunakan teknologi.
\end{abstract}

Kata kunci: TPR, bahasa, kreativitas, siswa

\begin{abstract}
English education is given to students in Indonesia starting at the elementary school level to university level. However, the characteristics of children as language learners are different and unique compared to adult learners therefore different methods are needed. The level of education in Jalancagak, Subang Village which is still uneven requires a refresher in learning methods, especially related to learning English. Community service entitled "The application of the TPR method to improve the ability to speak and creativity of students" aims to provide insight into kindergarten teachers about the application of TPR methods and provide the ability to teach primary school age children. The TPR (Total Physical Response) method is a method of language learning that is structured in the coordination of commands, speeches and actions; and trying to teach language through physical activity (motoric). The materials that were delievered regarding to the understanding, benefits, implementation and adaptation of the TPR method. It is hoped that teachers can apply this method in teaching and learning activities so as to improve students' speaking abilities and creativity while providing knowledge related to teaching methods both conventionally and using technology.
\end{abstract}

Keywords : TPR, language, creativity, students

\section{A. PENDAHULUAN}

Dalam ranah komunikasi global, Bahasa Inggris memegang peranan penting dan digunakan secara luas sebagai bahasa pergaulan, perdagangan dan pendidikan (Sayd, et al., 2018). Menyadari akan arti pentingnya penguasaan bahasa Inggris di era globalisasi 
ini, sehingga bahasa Inggris mulai diajarkan dari pendidikan dasar hingga pendidikan tinggi di Indonesia. Pada kenyataannya di Indonesia, Bahasa Inggris hanya dijadikan mata pelajaran yang diujikan pada tiap tahunnya untuk menilai kemampuan dan menentukan kelulusan maupun kenaikan jenjang studi siswa.Namun di dalam praktek keseharian,frekuensi untuk mempraktekkan dan membiasakan berkomunikasi Bahasa Inggris sangat rendah.

Salah satu masalah yakni pada pengajaran skill berbicara (speaking). Problematika yang terjadi pada pengajaran berbicara Bahasa Inggris di sekolah dasar pada umumnya dapat dipandang dari dua sisi.Dari sisi guru adalah masih minimnya metode pembelajaran yang menarik dan efektif guna mengasah kemampuan keterampilan berbicara Bahasa Inggris pada siswa sejak dini.Sedangkan dari sisi siswa sendiri adalah kurangnya motivasi,inisiatif,dan keterlibatan aktif selama proses pembelajaran. Problematika tersebut tentu saja akan berpengaruh pada prestasi belajar siswa yang tidak dapat maksimal.Oleh karena itu diperlukan suatu metode pembelajaran yang tepat untuk meningkatkan keterampilan berbicara dalam Bahasa Inggris.

Lokasi pengabdian adalah Desa Jalancagak yang terletak di Subang. Desa Jalancagak (Jalancagak Juara, 2014) terletak ditengah tengah diantara 6 Desa yang ada diwilayah Kecamatan Jalancagak yang menurut Sejarah Telah berdiri Sejak Tahun 1700 dengan nama DESA BUNIARA dan pada Tahun 1818 terjadi Perubahan Nama Desa yaitu dari DESA BUNIARA menjadi DESA BUNIHAYU . Kemudian pada tanggal 30 Desember 1980 terjadi Pemerkaran menjadi 2 (Dua) Desa yaitu DESA BUNIHAYU dan DESA JALANCAGAK.

Desa Jalancagak memiliki luas wilayah $332.250 \mathrm{Ha}$, yang terdiri dari 3 (Tiga) dusun, 5 Rukun Warga dan 33 Rukun Tetangga. Desa Jalancagak merupakan desa dengan dataran rendah yang berada di tengah-tengah diantara desa yang ada diwilayah Kecamatan Jalancagak yang ada di Selatan Kabupaten Subang 07 KM. Di sebelah utara berbatasan langsung dengan Desa Bunihayu, berbatasan dengan Desa Curugrendeng disebelah selatan. Disebelah timur dengan Wilayah Kecamatan Kasomalang dan berbatasan langsung dengan Wilayah Kecamatan Sagalaherang di sebelah Barat.

Berdasarkan referensi data Kemendikbud (sumber: http://referensi.data.kemdikbud.go.id/index11.php?kode=021900\&level=2) Indek Pendidikan dan Daya Beli penduduk Desa ini cukup tinggi dalam capaian IPM Desa 
Jalancagak sehingga membuat Desa Jalancagak IPM-nya dapat melebihi target IPM Kabupaten Subang. Di desa ini, sejumlah sarana prasarana sekolah maupun jenjang terus diupayakan baik kuantitas maupun kalitasnya, baik itu negeri maupun swasta, dari mulai TK/PAUD/RA s.d SLTA maupun Perguruan Tinggi Swasta. Namun memang pemerataan jumlah sekolah masih belum sesuai dengan jumlah penduduk yang umumnya sebagai petani dan berkebun, sehingga tingkat pendidikan masih harus terus ditingkatkan.

Banyak metode yang dapat diterapkan guru dalam mengajar bahasa Inggris terutama di tingkat sekolah dasar (Sayd, 2018). Pada prinsipnya, metode yang digunakan harus tetap berpegang pada prinsip bermain sambil belajar dengan mengacu pada DAP (Developmental Appropriate Practice) yakni pembelajaran harus disesuaikan dengan tingkat perkembangan anak. Metode yang diterapkan harus sesuai dengan karakterististik anak-anak sekolah dasar yang cenderung memiliki tingkat konsentrasi yang pendek serta membutuhkan lebih banyak latihan dan gerakan tubuh dalam memahami kosakata bahasa Inggris yang diajarkan (learning by accompanying actions) Salah satu upaya untuk meningkatkan keterampilan berbicara dalam Bahasa Inggris yakni dengan metode Total Physical Response (TPR) (Sayd, et al., 2018; Richard \& Rodgers, 2001; Larson-Freeman, 2000).

Dengan pemerataan jumlah sekolah yang masih belum sesuai, maka tingkat pendidikan dan pengajaran pun masih perlu ditingkatkan. Terutama dengan siswa usia muda atau young learners. Di kebanyakan daerah di Indonesia, bahasa Inggris masih dianggap menjadi bahasa asing yang sulit untuk dipelajari karena mereka lebih menyukai bahasa Ibu atau bahasa daerah. Sehingga guru-guru yang mengajar juga membutuhkan metode yang berbeda selain metode mengajar konvensional untuk menumbuhkan minat dan keahlian para siswa.

Salah satu metode yang dapat digunakan yaitu metode Total Physical Response (TPR). Metode TPR (Sayd, et al., 2018; Richard \& Rodgers, 2001; Larson-Freeman, 2000) merupakan suatu metode yang sangat baik untuk meningkatkan keterampilan berbicara pada siswa. Metode ini mementingkan koordinasi antara ujaran dan gerak. Metode ini merupakan metode pengajaran bahasa menggunakan aktivitas fisik motorik. Hal ini mendasari prinsip metode TPR yaitu pembelajaran menggunakan semua panca indera. Dengan metode ini, siswa dapat belajar melalui pengamatan, peragaan dan dengan melakukan tindakan sendiri. 
Metode TPR ini sangat mudah dan ringan dalam segi penggunaan bahasa dan juga mengandung unsur gerakan permainan sehingga dapat menghilangkan stress pada peserta didik karena masalah-masalah yang dihadapi dalam pelajarannya terutama pada saat mempelajari bahasa asing, dan juga dapat menciptakan suasana hati yang positif pada peserta didik yang dapat memfasilitasi pembelajaran sehingga dapat meningkatkan motivasi dan prestasi siswa dalam pelajaran tersebut. Makna atau arti dari bahasa sasaran dipelajari selama melakukan aksi. Guru atau instruktur memiliki peran aktif dan langsung dalam menerapkan metode TPR ini.

Menurut Asher (2006) , guru (instruktur) adalah sutradara dalam pertunjukan cerita dan di dalamnya siswa sebagai pelaku atau pemerannya. Guru yang memutuskan tentang apa yang akan dipelajari, siapa yang memerankan dan menampilkan materi pelajaran. Siswa dalam TPR mempunyai peran utama sebagai pendengar dan pelaku. Siswa mendengarkan dengan penuh perhatian dan merespon secara fisik pada perintah yang diberikan guru baik secara individu maupun kelompok.

\section{B. LANDASAN TEORI}

\section{Definisi TPR}

Menurut Richards \& Rodgers (2001) dalam bukunya Approaches and Methods in Language Teaching, Total Physical Response (TPR) didefinisikan "a language teaching method built around the coordination of speech and action; it attempts to teach language through physical (motor) activity" (Larson-Freeman, 2000). Jadi metode TPR (Total Physical Response) merupakan suatu metode pembelajaran bahasa yang disusun pada koordinasi perintah (command), ucapan (speech) dan gerak (action); dan berusaha untuk mengajarkan bahasa melalui aktivitas fisik (motor).

\section{Karakteristik anak-anak sebagai pembelajar bahasa}

Sebagai pembelajar bahasa, menurut Scott dan Ytreberg (1990) \& Moeslichatoen (2004) anak-anak memiliki karakteristik yang harus dipertimbangkan oleh guru dalam memberikan pengajaran kepada mereka. Berikut ini adalah beberapa karakteristik umum anakanak menurut Harmer, dikutip dari Sariyati(2017):

a. Mereka merespon makna walaupun tidak mengerti kata-katanya. Mereka sering belajar secara tidak langsung daripada secara langsung; 
b. Pemahaman mereka datang bukan hanya dari penjelasan, tetapi juga dari apa yang mereka lihat dan dengar dan penting bagi mereka memiliki kesempatan untuk menyentuh dan berinteraksi;

c. Mereka umumnya berantusias untuk belajar dan memiliki rasa ingin tahu tentang dunia di sekitar mereka;

d. Mereka membutuhan perhatian dan persetujuan dari gurunya;

e. Mereka tertarik berbicara tentang diri sendiri dan merespon dengan baik untuk belajar yang melibatkan diri sendiri dan kehidupan mereka sendiri sebagai topik utama di kelas;

f. Mereka kurang perhatian, kecuali pada kegiatan yang sangat menarik, mereka bisa cepat merasa bosan setelah berinteraksi setelah 10 menit atau lebih.

\section{Metode TPR}

Metode TPR ini sangat mudah dan ringan dalam segi penggunaan bahasa dan juga mengandung unsur gerakan permainan sehingga dapat menghilangkan stress pada peserta didik karena masalah-masalah yang dihadapi dalam pelajarannya terutama pada saat mempelajari bahasa asing, dan juga dapat menciptakan suasana hati yang positif pada peserta didik yang dapat memfasilitasi pembelajaran sehingga dapat meningkatkan motivasi dan prestasi siswa dalam pelajaran tersebut. Makna atau arti dari bahasa sasaran dipelajari selama melakukan aksi.

Total Physical Response dapat digunakan untuk mengajar dan mempraktekkan banyak hal seperti: (a) Kosakata yang berhubungan dengan tindakan, misalnya smile, chop, headache, cry. (b) Aspek-aspek pada tenses misalnya Every morning I brush my teeth, I make my bed, I eat breakfast, (c) Bahasa dalam ruang kelas, misalnya: open your book on page 14. (d) Kalimat perintah misalnya: sit down,stand up, close the door, serta (e) Bercerita. Pada dasarnya ini bisa diadaptasikan pada berbagai jenis situasi pembelajaran. Kita hanya membutuhkan imajinasi kita, bahkan siswa dapat dipancing untuk berimajinasi misalnya pada fase Join Construction siswa bisa meminta teman satu kelompoknya untuk melakukan sesuatu. Hal yang yang ganjil bisa saja diminta oleh siswa kepada temannya, seperti: Eat your thumb!, Eat the pencil!, Kiss your knee!, dan sebagainya. Kelas otomatis akan menjadi agak gaduh karena TPR memang melibatkan aktivitas lisan dan fisik. 


\section{METODE PELAKSANAAN}

Metode yang dipilih dalam melaksanakan kegiatan pengabdian masyarakat ini ini adalah pelatihan kepada para guru SMP bahasa Inggris yang berada di Desa Jalancagak, Subang. Para guru dari berbagai SMP ini telah memiliki banyak pengalaman sebagai guru namun secara umum mereka masih mengajar dengan cara konvensional, sehingga pelatihan dan penyuluhan dengan tema umum "pembelajaran inovatif berbasis media dan konvensional" dan tema khusus "penerapan metode TPR untuk meningkatkan kemampuan berbicara dan kreativitas siswa" diharapkan mampu meningkatkan keahlian guru dalam mengajar sekaligus memberikan pencerahan. Mereka akan diberikan pelatihan berupa pengertian TPR, implementasi TPR serta adaptasi kegiatan TPR.

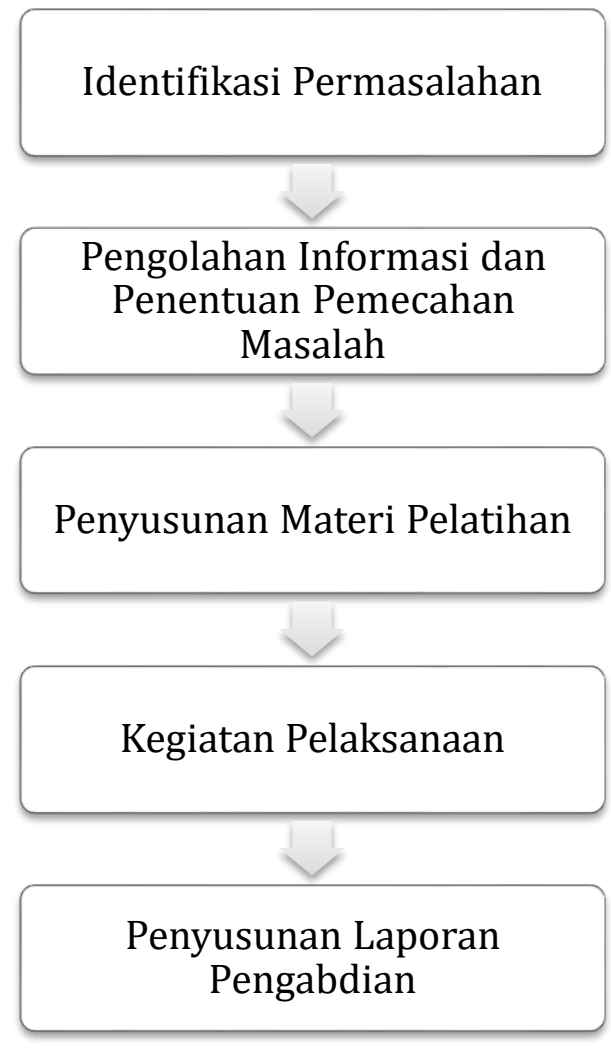

Gambar 1. Langkah pelaksanaan kegiatan pengabdian

Langkah-langkah kegiatan pengabdian ini dilaksanakan dalam 5 tahap sebagai berikut:

\section{Tahap 1. Identifikasi Permasalahan}

Pada tahap ini, tim pelaksana mengadakan observasi serta wawancara. Observasi dan wawancara ini dilaksanakan dengan berdiskusi dengan Kepala Desa, Kepala MGMP serta masyarakat sekitar untuk mengenali area dan memberikan masukan serta diskusi terkait kegiatan yang akan dilaksanakan. 


\section{Tahap 2. Pengolahan Informasi dan Penentuan Pemecahan Masalah}

Pada tahap ini tim pelaksana mengolah semua informasi baik berupa masukan hasil survei dan wawancara. Kajian teoretik dan empiris dikumpulkan terkait dengan usaha memberikan solusi terhadap masalah-masalah yang telah teridentifikasi. Adapun solusi yang segera perlu dilakukan adalah melalui pelatihan TPR untuk membantu guru mengatasi kejenuhan teknik mengajar secara konvensional.

\section{Tahap 3. Penyusunan Materi Pelatihan}

Pada tahap ini tim pelaksana mulai menyusun materi untuk hand-out yang akan diberikan kepada para peserta pelatihan serta mencari referensi yang sesuai.

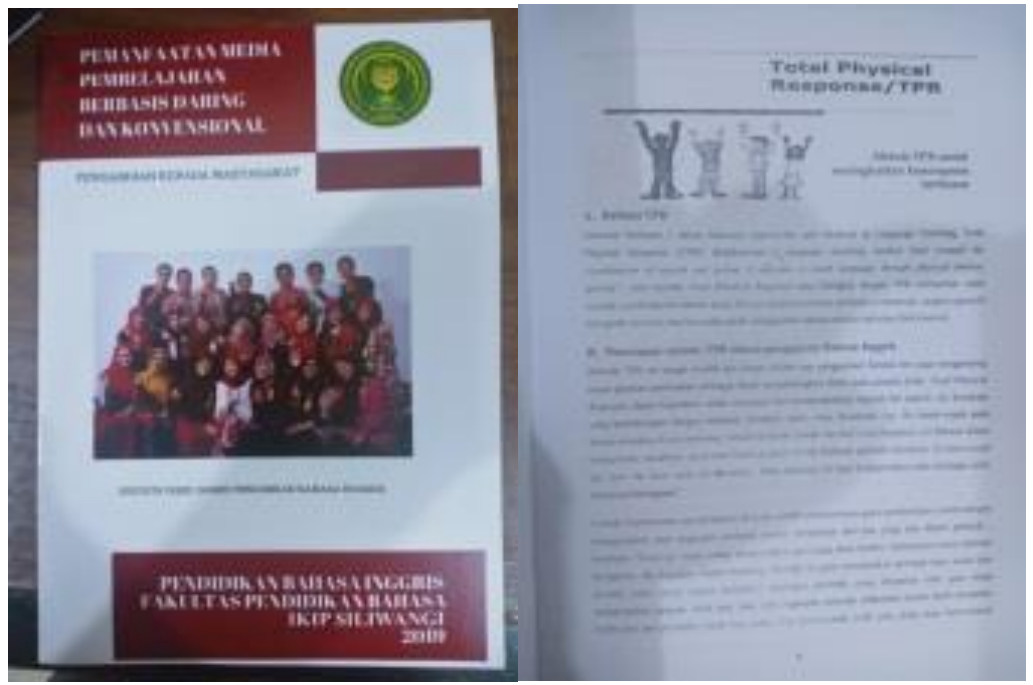

Gambar 2. Hand-out bagi peserta pelatihan

\section{Tahap 4. Kegiatan Pelaksanaan}

Pada tahap ini adalah kegiatan paling penting, yaitu pelaksaan aplikasi dari pelatihan penerapan kegiatan TPR untuk meningkatkan kemampuan berbicara dan kreativitas siswa. Kegiatan ini dilaksanakan di Gedung Olah Raga Desa pada tanggal 10 Agustus 2019 dari mulai pukul 08.00 hingga 12.00. Tim pelaksana memberikan pelatihan dan penerangan materi serta peserta mengadakan praktek setelah pemberian materi diberikan.
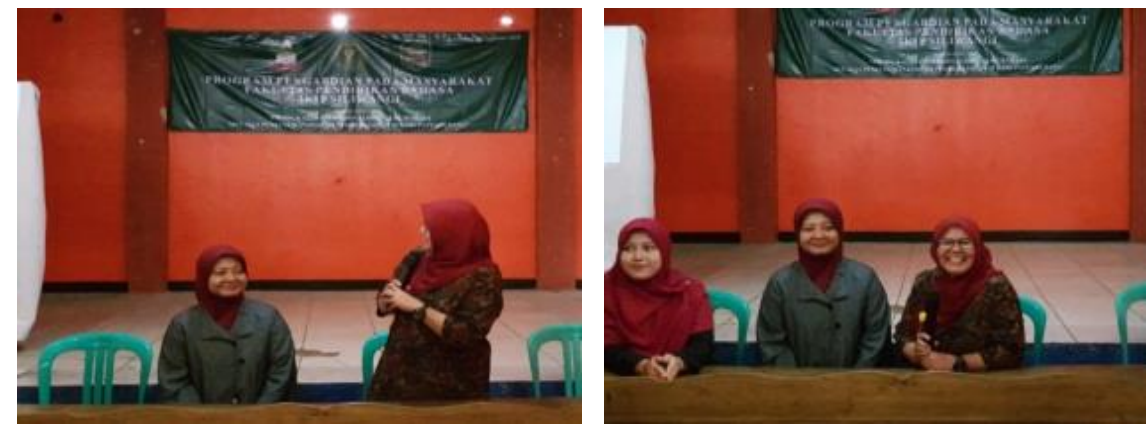

Gambar 3. Kegiatan pemberian materi 


\section{Tahap 5. Penyusunan Laporan Kegiatan Pengabdian}

Pada tahap ini adalah penyusunan laporan kegiatan dan hasil capaian pengabdian yang telah dilaksanakan. Penyusunan ini terdiri dari jurnal pengabdian kepada masyarakat dan laporan kegiatan secara mendetail.

\section{HASIL DAN PEMBAHASAN}

1. Peningkatkan pengetahuan dan keterampilan guru-guru bahasa Inggris dalam dalam melaksanakan pembelajaran dengan menerapkan metode TPR (Total Physical Response)

Setelah pelatihan ini para guru memperoleh pencerahan dan informasi terkait aplikasi, implementasi dan adaptasi TPR dan hal-hal yang bisa dilakukan di dalam kelas. Materi yang diterima oleh para guru antara lain:

a. Perbedaan metode mengajar cara konvensional dan menggunakan ICT

b. Pengertian TPR

c. Manfaat TPR

d. Kekurangan dan kelebihan dalam TPR

e. Ungkapan dan frase yang bisa digunakan dalam TPR

f. Adaptasi metode TPR untuk speaking

Bahwa dalam mengajar, peserta bisa menggunakan metode konvensional selain TPR antara lain menggunakan flashcard, media barang bekas dan lain sebagainya. Terkait mengajar menggunakan ICT, para peserta bisa meningkatkan kualitas pembelajaran dengan memanfaatkan media secara daring misalnya Kahoot, Padlet atau Google classroom dan lain sebagainya.

Pengertian TPR diberikan kepada para peserta dan secara umum peserta memahami bahwa TPR adalah metode memberikan perintah yang diberikan oleh guru pada siswa dan kemudian siswa merespon perintah tersebut. Metode ini bisa dimanfaatkan oleh pelajar pada level manapun, namun akan lebih baik bila diterapkan kepada young learner atau pelajar usia muda. Manfaat dari TPR ini adalah peserta memahami bahwa metode ini menarik, tidak membosankan dan bisa membuat siswa bergerak sekaligus melatih motorik mereka. Dalam bahasa Inggris terutama bisa melatih vocabulary dan spelling mereka. Dalam kekurangan dan kelebihan TPR, peserta memahami bahwa metode TPR tidak bisa dijadikan metode utama dalam setiap pembelajaran. Kelebihan dari TPR yang disimpulkan oleh peserta adalah bisa meningkatkan vocabulary dan 
motorik siswa namun kekurangannya adalah mungkin tidak akan terlalu membantu kepada siswa yang pemalu. Ungkapan dan frase yang bisa digunakan dalam TPR yang dipahami oleh para peserta berupa instruksi langsung dan spesifik, misalnya "touch your nose", "move the chair" dan lain sebagainya. Pemaparan materi terakhir terkait dengan metode TPR untuk meningkatkan kemampuan berbicara dan kreativitas siswa adalah dengan menggunakan media barang bekas. Dengan menggunakan media barang bekas, implementasi metode TPR bisa dikembangkan untuk meningkatkan kemampuan berbicara siswa. Misalnya adalah guru menggunakan media gambar atau foto yang diambil dari koran, lalu menyuruh siswa untuk memperagakan gerakan yang ada dalam foto atau bergantian menjelaskan apa yang ada dalam foto dengan teman sekelasnya.

\section{Pembahasan Pelaksanaan kegiatan}

Kegiatan ini dilaksanakan di Gedung Olah Raga Desa pada tanggal 10 Agustus 2019 dari mulai pukul 08.00 hingga12.00. Tim pelaksana memberikan pelatihan dan penerangan materi serta peserta mengadakan praktek setelah pemberian materi diberikan. Narasumber yaitu tim pelaksana memberikan materi dan selanjutnya memberikan contoh-contoh.

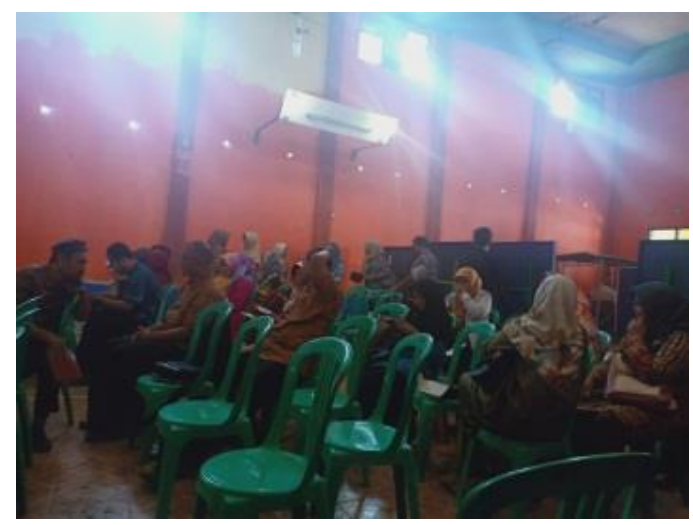

Gambar 4. Peserta mendengarkan pemaparan

Antusiasme para peserta dalam melaksanakan pembelajaran dengan penerapan metode dan adaptasi dari penerapan TPR serta menggunakan bahasa Inggris cukup baik. Walaupun tidak sempurna dan beberapa masih melakukan kesalahan, namun secara umum pelaksanaan berjalan dengan baik dan lancar. Hal ini membuktikan bahwa pelatihan yang diselenggarakan mampu memacu para guru untuk mengenal lebih banyak metode mengajar selain mengajar secara konvensional. 


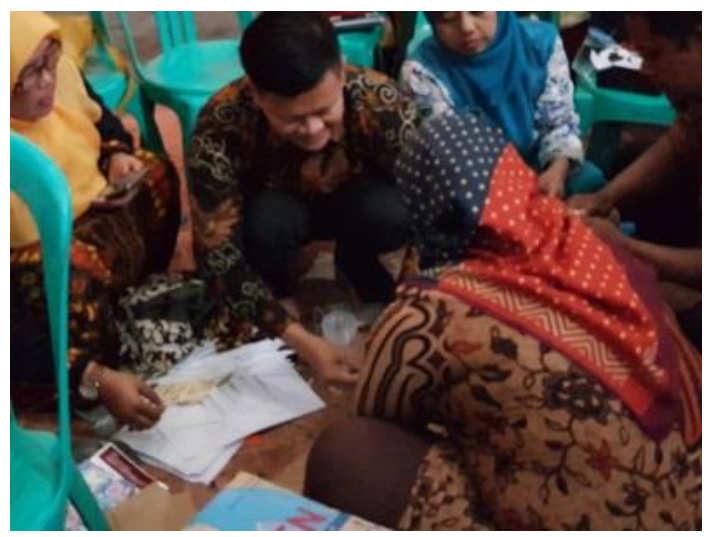

Gambar 5. Peserta berdiskusi

Acara penutupan dilakukan pada pukul 12.00 WIB yang dipandu oleh pembawa acara dengan memberikan laporan yang menyatakan bahwa kegiatan pengabdian masyarakat tersebut berjalan dengan lancar. Pada pidato penutupannya, narasumber berharap agar apa yang telah didapatkan dan apa yang telah dilatihkan bersama-sama hendaknya terus dipraktikkan di sekolah, agar dapat meningkatkan kompetensi bahasa Inggris, baik para siswa maupun para guru sebagai peserta pelatihan tersebut.

\section{E. KESIMPULAN}

Hal-hal yang dapat disimpulkan dari kegiatan pengabdian masyarakat ini adalah bahwa melalui kegiatan ini, IKIP Siliwangi Program Studi Bahasa Inggris Fakultas Bahasa dapat berpartisipasi dalam usaha peningkatan pengetahuan dan keterampilan para guru bahasa Inggris di Desa Palinggahan Kecamatan Plered Kabupaten Purwakarta melalui penyemaian informasi tentang pembelajaran bahasa Inggris melalui penyuluhan, penerapan serta adaptasi metode TPR (Total Physical Response) untuk meningkatkan kemampuan berbicara, kreativitas siswa serta pencerahan makna pada guru terkait metode mengajar konvensional dan teknologi.

Hal-hal yang dapat disarankan sesuai dengan simpulan di atas adalah sebagai berikut:

1. Peningkatan kualitas kegiatan belajar mengajar sebaiknya terus diupayakan untuk ditingkatkan, tidak dari pihak guru saja namun juga dari siswa agar percepatan peningkatan kualitas berjalan lebih baik;

2. Guru sebaiknya mengikuti perkembangan zaman teruama pemanfaatan internet agar lebih mengembangkan kemampuan belajar dan mengajar;

3. Guru sebaiknya lebih memahami kebutuhan siswa didalam kelas dan berupaya 
untuk memotivasi siswa terutama terkait dalam kemampuan berbahasa asing dalam hal ini adalah bahasa Inggris.

\section{F. UCAPAN TERIMA KASIH}

Mengucapkan terima kasih kepada Para jajaran pimpinan IKIP SILIWANGI, Dekan, Ketua Program Studi dan Ketua LPPM serta seluruh jajaran dosen program studi bahasa Inggris dan Fakultas Bahasa karena terselenggaranya acara kegiatan Hibah Pengabdian Kompetitif dan Kegiatan Pengabdian Masyarakat ini bisa berjalan dengan baik dan lancar.

\section{G. DAFTAR PUSTAKA}

Asher. (2006). Pembelajaran TPR. Diambil dari http://myopera.com.antariksa/blog.

Jalancagak Juara. (2014). Profil desa Jalancagak. Diakses di: http://desajalancagak.blogspot.com/2014/03/profil-desa-kondisi-desa-sejarah-desa.html.

Larsen-Freeman, D. (2000). Techniques and principles in language teaching. Oxford University Press.

Moeslichatoen, R. (2004). Metode pengajaran di taman kanak-kanak. Jakarta: PT. Asdi Mahastya.

Referensi Data Akademik, diakses di: http://referensi.data.kemdikbud.go.id/index11.php?kode=021900\&level=2).

Richard. J. \& Rodgers, T. (2001). Approaches and methods in language teaching. UK: Cambridge University Press.

Sariyati, Ice. (2017). Efektivitas penggunaan metode TPR dalam meningkatkan penguasaan vocabulary bahasa inggris pada siswa sekolah dasar. Jurnal Pendidikan Universitas Garut, 11 (1), 38-49, ISSN 1907-932X.

Sayd, A., Attubel, M., \& Nazarudin, H. (2018). Implementasi metode total physical response (tpr) dalam pembelajaran bahasa inggris bagi anak-anak sekolah dasar inpres liliba Kupang. Bisman-Jurnal Bisnis dan Manajemen, 3 (1), 17-24. ISSN $2477-2801$. Diambil dari

http://jurnalpnk.ac.id/index.php/bisman/article/view/244.

Scott, W. A., \& Ytreberg. (1990). Teaching english to children. New York: Longman, Inc. 